UDC 21.15.47

\author{
M. V. NESPRAVA ${ }^{1 *}$ \\ 1*Dnipropetrovsk State University of Internal Affairs (Dnipro, Ukraine), e-mail n.nesprava@ gmail.com, \\ ORCID 0000-0003-0415-1837
}

\title{
HUMAN IMAGE IN CLASSICAL ISLAM AND SUFISM: PHILOSOPHICAL ANALYSIS
}

Purpose. The study aims to obtaine data about the human image in Islam through thought of the respective visions of both the classical directions of the Muslim religion and the attitudes of Islamic mysticism (Sufism). Achievement of this goal involves the application of methods such as philosophical analysis, comparative method, phenomenology, as well as the consistent solution of the following tasks: a) to analyze the main manifestations of anthropological ideas in Islam; b) to comprehend the specificity of Muslim ideas about a human in comparison with the corresponding Christian teaching; c) to consider disagreements between the interpretation of the essence and tasks of a human in the classical Islam and Sufism. Theoretical basis. The author proceedes from the unsatisfactory nature of the superficial interpretation of the human image in Islam, according to which a human is often expounded as a "slave of Allah", neglecting the multidimensionality of the metaphysical status of a human in Islam, as well as the polyparadigmality of the human image in various Islam directons. Originality. The author refines the human image in Islam in two aspects: first - in the aspect of his conceptual content and secondly - in the aspect of his paradigmatic diversity. Conclusions. The widespread beliefs among the researchers concerning the anthropological component of Islam are not sufficiently substantiated, since they often do not take into account the ambiguity and multidimensionality of the ideas of the Muslim religion towards a human. As it has been shown, the general Muslim ideas about the metaphysical status of a human include two dimensions - a human is interpreted as "the slave of Allah", as well as "the vicegerent of Allah". Within this perception of the human nature there are two various paradigms for interpreting the sphere of preferential fulfillment of a human's duties as the slave and the vicegerent. The first one is used by the classical Islam, it was called the externalistic paradigm. The internalistic paradigm is used by Sufism. The author presents that the theme of the human image in Islam is still not sufficiently studied and it requires further research. The comprehension of the existing in Salafist and Shiite varieties of Islam concerning the human nature interpretation and their essence and tasks are the most productive areas of such further research.

Keywords: Islam; philosophical anthropology; human; Sufism; Quran

\section{Introduction}

Thematic justificationis: the question of the human image in Islam has not yet been resolved in philosophical and anthropological discourse. At present, stereotyped, simplified visions of this component of the Muslim doctrine are widespread in the existing literature, which makes it an important task to study the claimed subject matter. The scientific challenge that we problematize in this research is to clarify the conceptual content of the human image in Islam with the help of methodological means of philosophical anthropology. This theme is directly related to the current needs of domestic religious studies and other sciences that are engaged in the study of Islam and need support with philosophical studies in order to broaden their view of the issues under research.

It should be noted that among the authors who deal with the problems we are discussing, it is worth mentioning such researchers as M. Abdullah, J. Jones, E. Muzykina, M. Petersen, P. Polomoshnov, R. Rahmatullin, A. Smirnov, M. Faraponova. Thus, M. Abdullah studied the concept of the human in Islam during a comparative research of the ideas of "divine" and "human" in Islam and Christianity (Abdullah, 2016). J. Jones (2014) took up the theme "human" while studying such a direction in Islam as Shiism. E. Muzykina (2017) analyzed general data concerning Islamic anthropology. M. Petersen (2016) was interested in the subject of Islam in his study, devoted to the research of the Muslim organizations activities. P. Polomoshnov (2015) 
posed the problem of the need to study the doctrine of Islam about personality. R. Rahmatullin (2013) outlined the basic facts about the Sufi doctrine of the human. A. Smirnov (2000) researched the problem of the human's moral nature within the framework of the Arab-Muslim tradition. M. Faraponova (2014) conducted a comparative analysis of the understanding of a personality in Orthodoxy and Islam.

The originality of our research against the background of monographs and articles of the above-mentioned authors lies in the following two points. First, unlike these theorists, we apply the methodological apparatus of philosophical anthropology in our research. Secondly, we have highlighted the theoretical constructs of different directions in Islam, having seen the singularity of the anthropological concepts in classical Islam and Sufism.

\section{Purpose}

In our research, we seek to obtain data concerning the human image in Islam by considering both the classical variety of Islam and its leading mystical direction - Sufism. To achieve this purpose we used such methods as philosophical analysis, comparative method, phenomenology.

\section{Statement of basic materials}

The question of the human's essence is a fundamental philosophical problem. Its monistic idealistic paradigm is developed in the so-called Abrahamic religions, ranging from Judaism, then in Christianity, and finally in Islam. "Monism of the Abrahamic religions and corresponding to them idealistic teachings in its essence requires the assertion of significancy of the human role in implementing alternatives to good or evil" (Khanzhy, \& Lyashenko, 2017, p. 30).

Although, according to the researchers, in Islam, the concept of "human" has not obtained such active processing as in Christianity. This is due to the different modality of human data within the New Testament and Quran: "The goal of Quran is not to answer the question of what a person is, but the question of what a person has to do and does not, what is life goal, what is good and evil" (Faraponova, 2014, p. 157). Nevertheless, in Islam there are examples of thought the human image, the main components of which we consider in our study.

When theorists write about the human image in Islam, they firstly point to the Muslim interpretation of the human as a "slave of Allah". So, A. Smirnov emphasizes: «If you ask yourself what is the most typical characteristic of a person in the culture of Islam, then the answer will be the word "slave"» (Smirnov, 2000, p. 55). Such an interpretation of the human role is not something unique, and in other religions similar explanations are widespread.

The status of "slave" is determined primarily by the fact that, according to Islam, the human, like everything else, is the result of the creative activity of the Almighty. The existing status of the human assumes that he has certain responsibilities. First, it is the worship of the Almighty and the fulfillment of his attitudes. The basic duties of a Muslim are well known - it is shahadah, namaz, sawm, zakat, and hajj. Some directions in Islam, for example, salafism, add to these five "pillars of Islam" and jihad.

The question of human autonomy looks dubious in Islam. First, the human being as a creation, is something dependent, having a secondary character in the matter of decisionmaking. Secondly, the Muslim understanding of Predestination teaches that all events are predetermined by Allah, therefore the question of the human autonomy does not have stable ontological grounds, giving way to the ideas of fatalism. On the other hand, there are clear guidances in Quran that a person still has a certain degree of freedom. This even concerns the 
choice of religion - Quran indicates that representatives of different religions can live in a Muslim society, and Muslims should not proselytize by force people of other faiths.

So, in Islam there is an idea of certain human autonomy, which, however, is not perceived as the main feature of the human. Religious scholars point out that in Islam, «the concept of "freedom" in relation to the human is seen as something suspicious and connected with the escape from the righteous path» (Polomoshnov, 2015, p. 85). According to the visions of the Muslims, Allah established the world order and defined the mission of the human - to follow this order. However, in fulfilling its mission, a person has the opportunity to choose and be responsible for it.

The status of a slave is not the only component of Islamic anthropology. In Islam, the status of the human has another dimension, namely the role of Allah's vicegerent on the Earth (Faraponova, 2014, p. 157). This status has granted to a person that, according to Islam, exalts the human in comparison with other creatures of Allah - "knowledge of names", namely, 99 names of Allah. This knowledge makes the human Allah's vicegerent. According to religious scholars, the human carries out the vicegerency within the three spheres.

First, he has the ability to work on himself, striving to become better. Sec-

ondly, people are able to organize interpersonal relationships, striving to

build a decent society. Thirdly, according to Islam, people are able to man-

age their relationships with the outside world. (Muzykina, 2017, p. 108)

The metaphysical projection of the human in Christianity and in the main directions of Islam is significantly different. For example, Quran does not have the idea that a person is created in the image and likeness of God. The Holy Scripture of Muslims suggests the creation of a person in his own way. This reflects about a lower status of a person in the interpretation of Islam in comparison with the interpretation of the human's essence in Christianity.

When reading Quran, numerous phrases like "a human was created weak", "the human without gratitude", and so on stand out. However, it should be emphasized that such interpretations of the human are not a statement of manifestations of the original sin (the idea of original sin in Islam does not exist), represent an indication of the imperfect nature of the human as a creature. According to the Muslim doctrine, the human has been and is being prevented from image and likeness of God, he is imperfect from the beginning. However, in this case the human is not interpreted in Islam as an evil being. He is weak, but not angry. As A. Smirnov (2000) emphasizes: "According to the Islamic doctrine, human nature is not "desecrated", a person is not born with evil in the soul and does not bear the beginning of evil" (p. 52). Well, according to the Muslim doctrine, the human is weak, however, this is not a consequence of original sin, but only suggests to its imperfection. According to the Muslim visions, there is no reason to atone for mankind, because people do not have a nature spoiled by the original sin. So, those deep metaphysical questions that exist in Christianity regarding the creation of the human in the image and likeness of God, as well as concerning the idea of redemption, are not presented in Islam.

Researchers note that in many areas of Islam, interest regarding the human refers primarily to the issue of fulfilling their duties, whereas the idea of the human in Christianity is connected with comprehension primarily through her spiritual growth. P. Polomoshnov (2015) even writes: "The Islamic ideal of the human is a simple description of the set of external skills of an ideal 
Muslim without delving into his inner spiritual world and self-awareness" (p. 83). However, P. Polomoshnov's point of viewis only partially correct. The fact is that this researcher has overlooked that Islam as a worldview doctrine is not something homogeneous. There are various directions in it, and what is true in relation to the direction of classical Islam is not relative to, for example, Sufism. In this mystical flow of Islam, much attention is paid to the inner spiritual world of the human, his self-awareness.

Anthropological model of Sufism includes the doctrine of three aspects of the human: physical, social and spiritual.

The body level is the representation of the material world in the human in the form of physical and physiological processes, that stimulates low human aspirations, such as attraction to the satisfaction of bodily needs, as well as such manifestations as greed and envy. According to the teachings of Sufism, if the human identifies his "I am" with a bodily level, then this is a mananimal, driven by rough, low needs. For such a person, the concepts related to the social sphere or to spirituality are only empty words.

The social level is present in the human as the instance of society. These are certain social roles that the human acquires during his or her life, as a result of adaptation to one or another situation in society. For example, these are roles such as "father", "buyer", "teacher", etc. According to the Sufi doctrine, when the human identifies himself with this level, he is guided by social prestige, and higher things are unattainable to her/him.

The third level is the spiritual one - is the representation of the divine principle in the human. The task of the human, from the point of view of the Sufis, is the identification of his "I am" with precisely this level of his nature. For this, the human must be free from his social roles and animal passions and be dissolved in the divine. According to the teachings of the Sufis, this can be achieved only through the intense spiritual work in which the human creates himself: "If the first birth (birth of the body) is given by parents, the second birth - the birth of a person - gives society, then the third and last birth - the birth of the highest man, the God-man - may be only by their own efforts" (Rakhmatullin, 2013, p. 71).

The Sufi way of ascension to "the highest man" is the passing of three stages of the development: sharia, tariqah and haqiqah. At the Shariah stage, a Muslim is required to know and observe all norms of Islam. By preserving what was obtained at this stage, the Sufi goes further - to tariqah. Under the auspices of a teacher, a person is tought with asceticism and other spiritual and religious practices for the further liberation of the human from the domination of bodily and social factors in him/her. Success at this stage will, accordingly to the opinion of the Sufis, lead to the formation of a sense of organic connection with God, that is, to the state of haqiqah. Researchers describe the Sufi visions of the ideal of the human in this way: "On this path, there is a complete comprehension of the truth and liberation of an adherent with God. This is the state of the God-man, the holy man through which God "shines through", in whose words the Lord speaks" (Rakhmatullin, 2013, p. 72).

Consequently, we saw that in the interpretation of the human image in Islam, there are at least two basic approaches. The first, externalistic approach is directed "outwardly", first of all, with respect to the observance of external characteristics of the realization of human duties (classical Islam), the second is internalistic, the approach is directed at realization of duties primarily in relation to the "internal" transformation of a person spiritually (Sufism). Despite the specificity of these two approaches, in their essence, they are various manifestations of the same general Islamic conception of the metaphysical status of the human with his/her two dimensions: "the slave of Allah" and "the vicegerent of Allah", about which we spoke at the beginning of our research. 


\section{Originality}

Originality of this research is that with the help of the means of philosophical anthropology we have clarified the content of the human image in Islam in the following two points. First, in the aspect of conceptual content, having shown the general Islamic specific nature of visions concerning the metaphysical status of the human, which contains two basic dimensions - "the slave of Allah" and "the vicegerent of Allah". Secondly, in the aspect of the paradigmatic diversity of Islam, arguing the existence of two main types of human image in Islam - the externalistic (classical Islam) and internalistic (Sufism).

\section{Conclusions}

Based on the above, we came to the following conclusions. First, the human image in Islam is ambiguous and multidimensional. In particular, this is expressed in the presence of two dimensions of the metaphysical status of the human "the slave of Allah" and "the vicegerent of Allah", as well as the presence of two paradigmatic varieties of interpretation of the human image in Islam (the classical and mystical directions of Islam). Secondly, the theme of the human image in Islam requires the further research. As we see, the perspective directions of this paper may be the study of the specifics of the human image interpretation in Salafism, as well as in Shiism.

\section{REFERENCES}

Abdullah, M. (2016). Divinity and Humanity in Islam and Christianity. Exchange, 45(2), $141-153$. doi: 10.1163/1572543X-12341398 (in English)

Faraponova, M. A. (2014). Comparative analysis of interpretation of personality in orthodoxy and islam. Theory and Practice of Social Development, 19, 156-158. (in Russian)

Jones, J. (2014). Shiism, Humanity and Revolution in Twentieth-Century India: Selfhood and Politics in the Husainology of Ali Naqi Naqvi. Journal of the Royal Asiatic Society, 24(3), 415-434. doi: 10.1017/S1356186314000066 (in English)

Khanzhy, V., \& Lyashenko, D. (2017). Good and Evil as Vectors of Free Will in the Structure of Anthropic Time. Anthropological Measurements of Philosophical Research, 12, 27-39. doi: 10.15802/ampr.v0i12.119121 (in Russian)

Muzykina, E. V. (2017). The Concept of Person in Islamic Anthropology. Islamovedenie, 1, $105-111$. (in Russian)

Petersen, M. (2016). For Humanity Or for the Umma?: Aid and Islam in Transnational Muslim NGOs. United Kingdom: Oxford University Press. (in English)

Polomoshnov, P. A. (2015). Problema lichnosti v islame. Islamovedenie, 4, 78-88. (in Russian)

Rakhmatullin, R. (2013). Sufiyskaya antropologiya. Islamovedenie, 1, 64-74. (in Russian)

Smirnov, A. V. (2000). Nravstvennaya priroda cheloveka: Arabo-musulmanskaya traditsiya. Eticheskaya mysl, 1, 46-69. (in Russian)

\section{LIST OF REFERENCE LINKS}

Abdullah, M. Divinity and Humanity in Islam and Christianity / M. Abdullah // Exchange. - 2016. - Vol. 45, Is. 2. P. 141-153. doi: 10.1163/1572543X-12341398

Фарапонова, М. А. Компаративистский анализ понимания личности в православии и исламе / М. А. Фарапонова // Теория и практика общественного развития. - 2014. - № 19. - С. 156-158.

Jones, J. Shi'ism, Humanity and Revolution in Twentieth-Century India: Selfhood and Politics in the Husainology of 'Ali Naqi Naqvi / J. Jones // Journal of the Royal Asiatic Society. - 2014. - № 24, Is. 3. - P. 415-434. doi: $10.1017 / \mathrm{S} 1356186314000066$

Ханжи, В. Б. Добро и зло как векторы свободы воли в структуре антропного времени / В. Б. Ханжи, Д. Н. Ляшенко. // Антропологічні виміри філософських досліджень. - 2017. - Вип. 12. - С. 27-39. doi: 10.15802/ampr.v0i12.119121 
Музыкина, Е. В. Концепция человека в исламской антропологи / Е. В. Музыкина // Исламоведение. - 2017. № 1. - C. 105-111.

Petersen, M. For Humanity Or for the Umma?: Aid and Islam in Transnational Muslim NGOs / M. Petersen. United Kingdom : Oxford University Press, 2016. - 356 p.

Поломошнов, П. А. Проблема личности в исламе / П. А. Поломошнов // Исламоведение. - 2015. - № 4. C. $78-88$.

Рахматуллин, Р. Суфийская антропология / Р. Рахматуллин // Исламоведение. - 2013. - № 1. - С. 64-74.

Смирнов, А. В. Нравственная природа человека: арабо-мусульманская традиция / А. В. Смирнов // Этическая мисль. - 2000. - Вып. 1. - С. 46-69.

\section{B. HECПРАBA ${ }^{1 *}$ \\ 1* Дніпропетровський державний університет внутрішніх справ (Дніпро, Україна), ел. пошта n.nesprava@gmail.com, ORCID 0000-0003-0415-1837}

\section{ОБРАЗ ЛЮДИНИ В КЛАСИЧНОМУ ІСЛАМІ ТА СУФІЗМІ: ФІЛОСОФСЬКИЙ АНАЛІЗ}

Мета. Дослідження спрямовано на отримання даних стосовно образу людини в ісламі в процесі осмислення відповідних уявлень як класичних напрямків мусульманської релігії, так і настанов ісламського містицизму (суфізм). Досягнення цієї мети передбачає застосування таких методів, як філософський аналіз, компаративний метод, феноменологію, а також послідовне розв'язання таких задач: а) проаналізувати основні маніфестації антропологічних уявлень ісламу; б) осмислити специфіку мусульманських ідей про людину порівняно з відповідним християнським вченням; в) розглянути розбіжності між тлумаченням сутності та завдань людини в класичному ісламі та суфізмі. Теоретичний базис. Автор виходить із незадовільності поверхового тлумачення образу людини в ісламі, згідно з яким людина часто тлумачиться виключно як "раб Аллаха", упускаючи з уваги багатовимірність метафізичного статусу людини в ісламі, а також поліпарадигмальність образу людини в різних напрямках ісламу. Наукова новизна. Автором уточнений образ людини в ісламі в двох аспектах: по-перше, в аспекті його концептуального змісту, а по-друге, в аспекті його парадигмального різноманіття. Висновки. Поширені серед дослідників уявлення щодо антропологічної компоненти ісламу є недостатньо грунтовними, адже часто вони не враховують неоднозначність та багатовимірність ідей мусульманської релігії щодо людини. Як було показано, загальноісламські уявлення про метафізичний статус людини включають в себе два виміри - людина тлумачиться як "раб Аллаха", а також, як "намісник Аллаха". В межах цього сприйняття сутності людини наявні різні парадигми тлумачення сфери переважного виконання обов'язків людини як раба та намісника - екстерналістська (класичний іслам) та інтерналістська (суфізм). Було показано, що тема образу людини в ісламі все ще недостатньо вивчена та потребує подальших досліджень. Найбільш продуктивними напрямками цієї подальшої дослідницької роботи є осмислення наявних в салафістських та шиїтських різновидах ісламу уявлень про людину, ії сутність та завдання.

Ключові слова: іслам; філософська антропологія; людина; суфізм; Коран

\section{Н. В. НЕСПРАВА ${ }^{1 *}$}

\footnotetext{
${ }^{1 *}$ Днепропетровский государственный университет внутренних дел (Днипро, Украина), эл. почта n.nesprava@gmail.com,
} ORCID 0000-0003-0415-1837

\section{ОБРАЗ ЧЕЛОВЕКА В КЛАССИЧЕСКОМ ИСЛАМЕ И СУФИЗМЕ: ФИЛОСОФСКИЙ АНАЛИЗ}

Цель. Исследование направлено на получение данных об образе человека в исламе посредством осмысления соответствующих представлений как классических направлений мусульманской религии, так и установок мистического направления ислама - суфизма. Достижение данной цели предусматривает применение таких методов, как философский анализ, компаративный метод, феноменологию, а также последовательное решение следующих задач: а) проанализировать основные манифестации антропологических представлений 
ислама; б) осмыслить специфику мусульманских идей о человеке по сравнению с соответствующим христианским учением; в) рассмотреть разногласия между толкованием сущности и задач человека в классическом исламе и суфизме. Теоретический базис. Автор исходит из неудовлетворительности поверхностного толкования проблемы образа человека в исламе, которое часто трактует человека исключительно как "раба Аллаха", упуская из виду двухмерность метафизического статуса человека в исламе, а также полипарадигмальнисть образа человека в разных направлениях ислама. Научная новизна. Автором уточнён образ человека в исламе в двух аспектах: во-первых, в аспекте его концептуального содержания, а во-вторых, в аспекте его парадигмального разнообразия. Выводы. Распространённые среди исследователей представления об антропологической компоненте ислама недостаточно основательны, поскольку часто они не учитывают неоднозначность и многомерность идей мусульманской религии относительно человека. Как было показано, общеисламские представления о метафизическом статусе человека включают в себя два измерения - человек толкуется как "раб Аллаха", а также как "наместник Аллаха". В рамках этого восприятия сущности человека имеются различные парадигмы толкования сферы преимущественного выполнения обязанностей человека как раба и наместника - экстерналистская (классический ислам) и интерналистская (суфизм). Было показано, что тема образа человека в исламе все еще недостаточно изучена и требует дальнейших исследований. Наиболее продуктивными направлениями этой дальнейшей исследовательской работы является осмысление имеющихся в салафистской и шиитской разновидностях ислама представлений о человеке, его сущности и задачах.

Ключевые слова: ислам; философская антропология; человек; суфизм; Коран

Received: 24.11.2017

Accepted: 21.03.2018 